\title{
IMPROVING POST-PARTUM HEALTH USING HERBAL SOURCES
}

\author{
Ida Maryati $^{1}$, Anita Setyawati ${ }^{1}$ \\ Faculty of Nursing, Universitas Padjadjaran \\ Corresponding email: ida.maryati@fkep.unpad.ac.id
}

\begin{abstract}
The postpartum period is a time after the placenta is born until 40 days later, during this period there is a process of returning the physical condition of the mother after conceiving and giving birth. In the process of returning this physical condition requires more attention because there is a possibility of upcoming problems such as bleeding, infection, breastfeeding disorders, vascular disorders, and psychological. There have been several efforts made to support the improvement of postpartum maternal health, both using professional care and through traditional treatments such as the use of herbs. The purpose of this study was to identify the benefits of herbal medicines and their effectiveness in improving mothers' health in the puerperium. This study used a literature review approach through search in the Google Scholar, EBSCO, and Proquest databases with keywords: herbal, post-partum, and health promotion. In this study, 12 journals were obtained regarding the use of herbs used by women in the puerperium period to improve their health. Herbs used to improve maternal health include: purple sweet potato leaves, katuk leaves, turmeric, lempuyang, tamarind, green bean extract, black meeting, aloe vera, kalendula flowers, binahong leaves, rosella flowers, bitter orange, and lavender. The use of this herb serves to help repair reproductive organs to recover as before pregnancy.
\end{abstract}

Keywords: Herbal, health promotion, postpartum.

\section{INTRODUCTION}

The maternal mortality rate (MMR) in Indonesia is still high, ranging from 305 deaths per 100,000 live births. Numbers of these maternal deaths occurred in the puerperium, which is six hours to 42 days postpartum (Nirwarna, 2011; Profile of Indonesian Health, 2016). In this postpartum period, postpartum mothers experienced a process of returning physical and psychological conditions that required more attention because they were susceptible to problems such as bleeding, labor wound infections, breastfeeding disorders, vascular disorders, and other physical and psychological problems.

There are several efforts made to support the health improvement of postpartum mothers, not only by professional care but also with the use of traditional treatments such as herbs. The use of traditional medicines or herbal medicines for health has been carried out in various countries including developed countries and their effectiveness is recognized through several kinds of research and supported by world health organizations.

In Indonesia, the use of herbs to improve postpartum maternal health has been widely carried out because it is supported by hereditary cultures and traditions. The use of herbs in postpartum mothers is believed to accelerate wound healing, increase the production of breast milk and it is believed to reduce stress in postpartum mothers (Pratiwi, 2018). 
Ida Maryati : Improving Post-Partum Health Using Herbal Sources

The policy on the use of herbs in Indonesia is regulated under Constitution Law No. 23 the year 1992 concerning health which states that if traditional medicines are ingredients or formula in the form of plant, animal, mineral, which can be used for treatment. The use of herbs is one alternative for postpartum maternal health promotion. The use of this herb usually utilizes elements that exist in nature, the raw material is easy to find and does not contain chemical elements (Dwisatyadini, 2010). However, studies that explore herbs comprehensively are limited. The purpose of this study was to identify the benefits of herbs and their effectiveness in improving mothers' health in the puerperium period.

\section{METHODS}

In conducting a literature review, the database used to search for journals/articles were Google Scholar, EBSCO, and Proquest. The keywords were herbal, post-partum, and health promotion. Journals/articles were published no more than 10 years ago. After conducting a search, 12 journals/articles were selected that examined topics and suitable for this study. From the 12 articles, 8 articles were examined various herbs from any regions in Indonesia, then 4 articles were studies from out of Indonesia.

\section{RESULTS}

Indonesia is one of the countries that have high potential in utilizing herbs. This is supported by the condition of Indonesia that has a tropical climate and has very diverse plants. Along with the development of science and technology, the use of herbs as a treatment and improvement in health has started again. This is in accordance with the Basic Health Research in 2010 conducted by the Ministry of Health stated $59.12 \%$ of the population had consumed jamu (traditional Indonesian herbal medicine made from turmeric, ginger, and other herbs) and $95 \%$ of that amount acknowledged the benefits of traditional herbs for health (Kus, 2013).

The use of herbs from generations to generation is not only to treat a particular disease but is also used to improve the health of women who are in the puerperium. The use of herbs used for postpartum mothers helps to repair reproductive organs to recover as before pregnancy. This article present review results of 12 research articles.

\section{DISCUSSION}

The following describes types of herbs and the usefulness for post-partum:

\section{The use of herbs to increase breastmilk production}

The herbs can help to increase milk production in postpartum mothers. This is because the content in herbs can stimulate milk production. Herbal plants, such as purple sweet potato leaves, 
Ida Maryati : Improving Post-Partum Health Using Herbal Sources

katuk leaves, turmeric, lempuyangan, tamarind, green bean extract, and dates if consumed regularly, would increase the amount of prolactin and breastmilk (Baequny, 2016; Kusuma, Setiani, Umaroh, Pramono, Widyawati, and Kumorowulan , 2017; Sakka, Salama, and Salama, 2014; Wulandari and Jannah, 2015).

Research conducted by Kusuma, Setiani, Umaroh, Pramono, Widyawati, and Kumorowulan, (2017) at Boyolali Community Health Center using a quasi-pretest-posttest design on 30 postpartum mothers using an enzyme-linked immunosorbent assay (ELISA) to measure prolactin levels, while breast milk production measured based on breastmilk volume and infant weight, the results showed that purple sweet potato leaves can significantly increase prolactin levels and the amount of breast milk. This is because sweet potato leaves contain lipid structure elements and hormones in which active compounds are actively involved in milk production because they performed a lactagogue effect. Lactagogue is a substance contained in sweet potato leaves that can facilitate breastmilk. In addition, according to the nutritional quality index, sweet potato leaves are good sources of protein, fiber, and minerals, especially $\mathrm{K}, \mathrm{P}, \mathrm{Ca}, \mathrm{Mg}, \mathrm{Fe}, \mathrm{Mn}$, and $\mathrm{Cu}$ (Sun, Mu, Xi, Zhang, and Chen, 2014)

Other study conducted in Cairo and India by Sakka, Salama, and Salama in 2014 showed that fenugreek tea and dates can increase milk production and baby weight. The same effect will be obtained if mothers consume green bean juice, this research was conducted in Jombang by Wulandari and Jannah in 2015. Postpartum mothers can consume green bean juice in a variety of processed foods such as green bean porridge, green bean drinks, traditional cakes, and or dishes with green bean sprouts.

However, in the Gunanegara study, Suryawan, Sastrawinata (2010), katuk leaves (Sauropus androgynous) did not provide a significant difference in increasing milk production when compared with placebo. Katuk leaves have been known in traditional medicine in South Asia and Southeast Asia as an enhancing drug for breast milk.

The things to do to help mothers who have less breastmilk production is by consuming katuk leaves. This plant is traditionally used to increase and expedite milk. Breastfeeding mothers are encouraged to consume katuk leaves, by using a mixture of clear vegetables, boiled vegetables or a mixture of rice. Now katuk leaves can be consumed easily. Katuk leaves are made in the form of capsules ready to drink containing $100 \%$ green leaf extract which is processed naturally and hygienically without any additional ingredients and while maintaining the benefits of katuk leaves. Without any side effects, katuk leaf capsules are safe to be consumed by breastfeeding mother and cure several diseases. 


\section{The use of herbs for healing perineal wounds}

After giving normal birth, several mothers experienced torn sores on the perineum and it turns out that some herbs can speed up the wound healing process. After the research was done, it turned out that the postpartum mother who was given black Temu extract/Curcuma aeruginosa recovered her perineum 5 days faster with the wound was already dried and the stitches had closed. But no studies have found the side effects or contraindications to this herb (Wahyuningrum, Khalimatus, Khusniyati, 2016)

In addition to the use of herbs above, the use of aloe vera ointment and kalendula flower can accelerate episiotomy wound healing. This research was conducted by Eghdampour, Jahdie, Kheyrkhah, Taghizadeh, Naghizadeh, and Hagani, in 2013 using the true experimental design. This clinical trial involved 111 eligible primiparous women who were hospitalized at Lolagar hospital. They were randomly categorized into the control group and the experimental group. The women in the experimental group used Aloe vera and Calendula Ointment every 8 hours and the control group routinely used the hospital for episiotomy for 5 days. The results showed that wound healing perineum in the experimental group was faster than the control group.

Redness, edema, and ecchymosis in perineal wounds are reported to decrease significantly. However, this ointment should not be used by mothers who have a history of sensitivity to special medicines (Eghdampour, Jahdie, Kheyrkhah, Taghizadeh, Naghizadeh, and Hagani, 2013). Giving boiled water of binahong leaves has a faster wound healing effect (3-8 days) compared to wound healing with Povidone Iodine (5-10 days) (Riyanto, 2018). 


\section{The use of herbs for postpartum hypertension}

The research result by Ritonga, Setiani, Umaroh, and Amri (2017) on 30 postpartum mothers in three General Hospitals, namely Ambarawa Hospital, Ungaran, and Semarang, found that the use of herbs proved to reduce blood pressure in postpartum mothers. The herbs used are Roselle Flowers (Hibiscus sabdariffa), dried roselle petals mixed with $200 \mathrm{ml}$ of hot water at a temperature of $90^{\circ} \mathrm{C}$. After the consumption, it can reduce systolic pressure by an average of $5 \mathrm{mmHg}$ and diastolic pressure $5.33 \mathrm{mmHg}$. The general mechanism of this medicinal plant is to control blood pressure through the effect of dilated blood vessels and reduce the kidney's ability to increase blood pressure (Da-CostaRocha, Bonnlaender, Sievers, Pischel, and Heinrich, 2014). But side note, this herb is not intended for postpartum mothers with a history of hypotension, impaired kidney function, impaired liver function, and digestive disorders.

\section{The use of herbs for pain after cesarean section}

From several studies conducted by several researchers saying aromatherapy with any sensation can reduce pain, improve sleep quality, and reduce anxiety. The aroma of bitter orange and lavender therapy is proven to be able to reduce pain especially pain after cesarean section and can reduce anxiety in pregnant women during labor (Anwar, Astuti and Bangsawan, 2018; Utami, 2016).

\section{CONCLUSION}

Herbs can be used as an additional therapy for postpartum mothers as a health support stimulant. In postpartum mothers who are breastfeeding, it is recommended to reduce the consumption of drugs made from chemicals because it will affect the quality of breast milk. Based on the results of the analysis, herbs can provide benefits to improve the health of postpartum mothers, including accelerating the process of healing the perineum wound, reducing postoperative cesarean pain, increasing milk production, reducing blood pressure in mothers with postpartum hypertension, and reducing depression and anxiety levels of childbirth mother.

\section{REFERENCES}

Baequny Ahmad, Supriyo ., Sri Hidayati. (2016). Efektivitas Minum Jamu (Ramuan Daun Katuk, Kunyit, Lempuyangan, Asem Jawa) Terhadap Produksi ASI Pada Ibu Nifas. DOI: http://dx.doi.org/10.31941/jurnalpena.v30i1.403 
Ida Maryati : Improving Post-Partum Health Using Herbal Sources

Da-Costa-Rocha, I., Bonnlaender, B., Sievers, H., Pischel, I., \& Heinnrich, M. (2014). Hibiscus sabdariffa L. - A phytochemical and pharmalgical review. Food Chemistry, 165, 424-443. https://doi.org/10.1016/j/foodchem.2014.05.002

Dwisatyadini, M. (2010). Pemanfaatan Tanaman Obat Untuk Pencegahan dan Pengobatan Penyakit Degeneratif. Optimalisasi Peran Sains dan Teknologi Untuk Mewujudkan Smart City, 237-270.

Eghdampour, F., Jahdie, F., Kheyrkhah, M., et al. (2013). The Impact of Aloe vera and Calendula on Perineal Healing after Episiotomy in Primiparous Women: A Randomized Clinical Trial. Journal of Caring Sciences, 2(4), 279-286.

Gunanegara, R., F., Suryawan, A., Sastrawinata, U., S. 2010. Efektivitas Ekstrak Daun Katuk dalam Produksi Air Susu Ibu untuk Keberhasilan Menyusui. Jurnal Kesehatan Mayarakat. 9(2): 105-117.

Imron, Riyanto dan Isnaeni. (2018). Perbedaan Efektifitas Povidone Iodine Dengan Air Rebusan Daun Binahong Terhadap Penyembuhan Luka Perineum Pada Ibu Postpartum Di Bpm Wilayah Kerja Dinas Kesehatan Kabupaten Lampung Selatan Tahun 2017. Sakai Sambayan - Jurnal Pengabdian kepada Masyarakat, 2(2), 61-68.

Kusuma, I. C., Setiani, O., Umaroh, Pramono, N., Widyawati, M. N., \& Kumorowulan, S. (2017). Sweet Potato ( Ipomoea Batatas L .) Leaf: Its Effect on Prolactin and Production of Breast Milk in. Belitung Nursing Journal, 3(2), 95-101.

Nirwana, A. B., 2011, Psikologi Ibu, Bayi dan Anak, Nuha Medika, Bantul

Ou, Heng., Amely, G., \& Marisa, B. (2016). The First Forty Days: The Essential Art of Nourishing the New Mother. New York: Abrams. Diakses di https://books.google.co.id/books?id=lNaiCwAAQBAJ\&printsec=frontcover\&dq=postpartum+care $\& \mathrm{hl}=\mathrm{en} \& \mathrm{sa}=\mathrm{X} \& \mathrm{ved}=0 \mathrm{ahUKEwjXiaW} \_9 \mathrm{aDeAhWTXCsKHSo6D6AQ6AEIKjAA \# v=onepage \& q=}$ postpartum\%20care \&f=false pada 26 Oktober 2018

Pratiwi, R. S. (2018). Pengobatan Tradisional (Jamu) Dalam Perawatan Kesehatan Ibu Nifas dan Menyusui di Kabupaten Tegal. Jurnal Siklus, 7(1), 263-267.

Profile Kesehatan Indonesia. (2015). Jakarta: Kementrian Kesehatan RI

Ritonga, N. J., Setiani, O., Umaroh, Budhi, K., \& Amri, F. (2017). Roselle flowers (Hibiscus sabdariffa) in the treatment of hypertension in postpartum mothers. Belitung Nursing Journal, 3(3), 229-237.

Sakka, A. El, Salama, M., \& Salama, K. (2014). The Effect of Fenugreek Herbal Tea and Palm Dates on Breast Milk Production and Infant Weight. Journal of Pediatric Sciences, 6. https://doi.org/http://dx.doi.org/10.17334/jps.30658.

Sun H, Mu T, Xi L, Zhang M, Chen J. Sweet potato (Ipomoea batatas L.) leaves as nutritional and functional foods. Food 2014;156:380-389. 
Ida Maryati : Improving Post-Partum Health Using Herbal Sources

Utami, S. (2016). Efektivitas Aromaterapi Bitter Orange Terhadap Nyeri Post Partum Sectio Caesarea. Unnes Journal of Public Health, 5(4), 316-323. https://doi.org/10.15294/ujph.v5i4.12422

Wahyuningrum, T., Sa'diyah, L. K., \& Khusniyati, E. (2018). Efek Curcuma Aeruginosa Terhadap Penyembuhan Perineum Ibu Postpartum di BPM Amirul dan BPM Panca Mojokerto. Media Ilmu Kesehatan, 7(1), 22-27.

JMCRH: Vol. 2 Issue 2 